\title{
Nondestructive Analysis of Silver Coins Minted in Taras (South Italy) between the V and the III Centuries BC
}

\author{
Alessandro Buccolieri, ${ }^{1}$ Giovanni Buccolieri, ${ }^{2}$ Emanuela Filippo, ${ }^{1}$ Daniela Manno, \\ Giuseppe Sarcinelli, ${ }^{3}$ Aldo Siciliano, ${ }^{3}$ Rosa Vitale, ${ }^{4}$ and Antonio Serra ${ }^{3}$ \\ ${ }^{1}$ Dipartimento di Scienze e Tecnologie Biologiche e Ambientali, Università del Salento, Via Monteroni, 73100 Lecce, Italy \\ ${ }^{2}$ Dipartimento di Matematica e Fisica, Università del Salento, Via Monteroni, 73100 Lecce, Italy \\ ${ }^{3}$ Dipartimento di Beni Culturali, Università del Salento, Via D. Birago No. 64, 73100 Lecce, Italy \\ ${ }^{4}$ Dipartimento di Lettere e Beni Culturali (DiLBEC), Seconda Università di Napoli, Santa Maria Capua Vetere, 81055 Caserta, Italy
}

Correspondence should be addressed to Alessandro Buccolieri; alessandro.buccolieri@unisalento.it

Received 24 October 2013; Accepted 18 May 2014; Published 16 June 2014

Academic Editor: Yue-Xing Feng

Copyright (C) 2014 Alessandro Buccolieri et al. This is an open access article distributed under the Creative Commons Attribution License, which permits unrestricted use, distribution, and reproduction in any medium, provided the original work is properly cited.

\begin{abstract}
This work enters in an interdisciplinary research project involving the archaeometrical analysis of ancient silver coins minted in the Greek colony of Taras (the modern south Italian town of Taranto) between the V century BC and the III century BC. In this work, by comparing the results obtained from X-ray microanalysis data acquired from the least corroded surface areas and the crosssection of coins from SEM-EDX and from XRF analysis, we have demonstrated that analysed coins exhibited a corrosion layer no more than $25 \mu \mathrm{m}$ and that surface silver enrichment was less than $1 \mathrm{wt} \%$. Thus, the data obtained by using X-ray microanalysis from surface may not significantly differ from the original bulk composition. Our results demonstrate that the silver content in the coins decreases considerably ranging from about $97 \%$ for the older down to $80 \%$ for the ones of 3rd Evans period (300-270 BC), corresponding to the significant social change in the period.
\end{abstract}

\section{Introduction}

The cooperation between analytical physicists and numismatists is in expansion because they are confronted with problems that traditional methods of numismatics cannot solve. Elemental analysis of ancient coins presents increasing interest due to their direct relation with economy and metallurgy of the minting time. The minting time is usually determined with very good accuracy by the numismatists from the examination of the features of the coin.

There are three separate areas of interest where cooperation can take place between the scientist and numismatist: (1) results of analysis for major components may provide information on the minting technology of the period $[1,2]$ and may also help in studies of economical development [3]; (2) the determination of the minor and trace elements can give suggestions regarding the provenance of the metal used [4-10] or contamination introduced during manufacture; (3) microscopic examination may yield important information regarding the type of metallurgical processes used during the manufacture of coins [1].

Coinage has always been a prime target for debasement or production of copies of ancient issues because of the immediate financial reward that results [11].

It has been known for a long time that the chemical composition on the surface of old coins sometimes differs from that in the bulk $[12,13]$.

The advent of accurate and nondestructive physical techniques, such as X-ray fluorescence analysis (XRF), electron probe microanalysis (EPMA), and particle induced X-ray emission (PIXE), was synonymous with great changes in metallic analysis applied to numismatics and to cultural heritage. Ancient silver coins represent objects unique and of high value and any investigation must be nondestructive; that is, no original sample material should be removed and the object itself should not be modified in any way during examination. 
XRF, EPMA, and PIXE are commonly recognized as surface methods since only a surface layer of limited depth (from a few micrometres up to a few tens of micrometres) is analyzed. In case of noble metals, surface enrichment for gold or silver alloys has been reported by several authors $[14,15]$. When the surface of objects is altered, the above-mentioned techniques (XRF, EPMA, and PIXE) are considered limited to providing us with data mainly for the surface material which is not representative for the bulk of the object, since the composition of the object cannot be considered homogeneous in depth, after the alteration [16].

The aim of this work is to make an attempt to evaluate the surface enrichment of silver-copper alloy coins at different investigation depths by means of SEM-EDX analysis performed at different acceleration voltage of incoming electrons [17]. Before performing analysis, the instruments were calibrated by means of silver-copper standards of various compositions, reflecting the composition of silver blanks. Therefore additional investigations were carried out by SEMEDX on cross-sections of specific fragments of coins. By $\mathrm{X}$-ray data acquired from the cross-section, the relative enrichment of silver due to the corrosion process could be detected and evaluated [18].

The performed SEM-EDX analysis was then compared to the one obtained by XRF. We mainly aimed at showing the cases for which SEM-EDX can provide useful information about the analysed objects. We would also stress the convenience to perform simultaneously the morphological and compositional surface analysis of each coin. Examined coins were accurately chosen since they are representative of origin context, conditions of recovery, or modalities of conservations. In order to have a representative sample, several series for every group have been selected from the collection of the National Museum of Taranto. The fortyfive analysed ancient silver coins coming from collection of the National Museum of Taranto were minted by the Greek colony of Taras (the modern South Italian town of Taranto) between the V century BC and the III century BC [19-24]. They range between the beginning phase of double relief issue and the Evans VII period series. Moreover, they were until now lacking in their technical and numismatic articulation, their chemical composition, and so on [25].

In addition, in order to estimate the effectiveness of the issue procedures and the reliability of the data, three coins of Corinth (label C) and one Arpi's fractions (label A) have been used as comparison in this first phase of investigation.

All analysed samples derived from sites near Taranto (Figure 1). Taras was founded in 706 BC by Dorian Greek immigrants as the only Spartan colony and it increased its power becoming a commercial tow of Magna Grecia thanks to its enviable position, in the centre of Mediterranean Sea.

The groups of coins were chosen in order to compare different samples coming from different areas. Origin contexts, conditions of recovery, or modalities of conservation can discriminate the various pieces. In order to have a representative sample, several series for every group have been examined.

The first group includes three series, chronologically arranged between the finish of VI century and the beginning

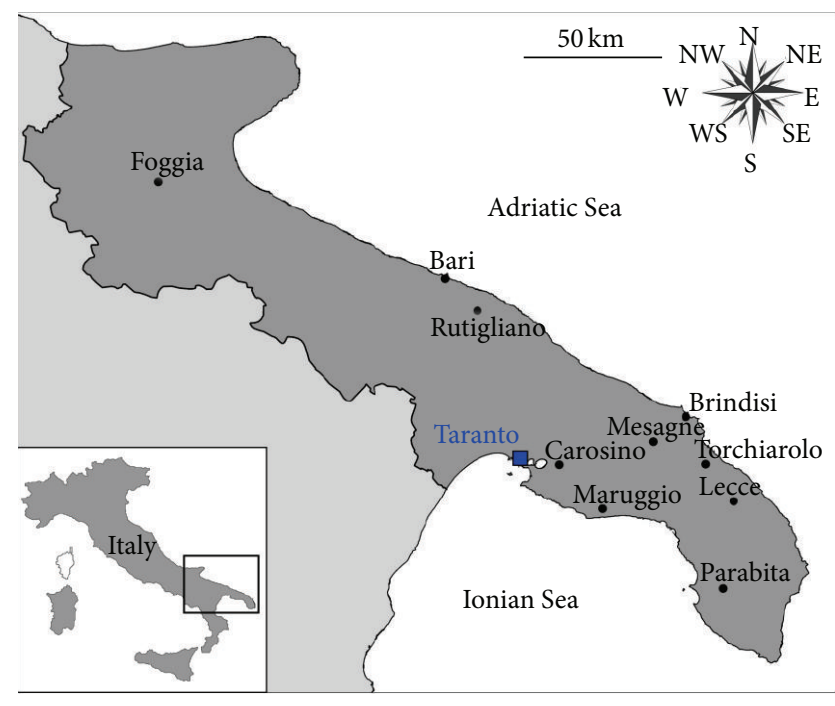

FIGURE 1: Map of the sites where the coins were found (Apulia, South Italy).
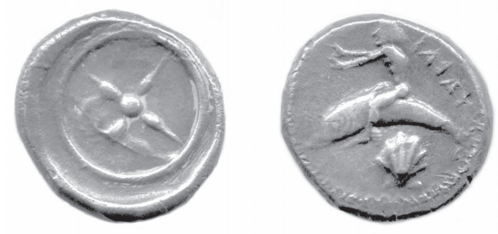

(a)
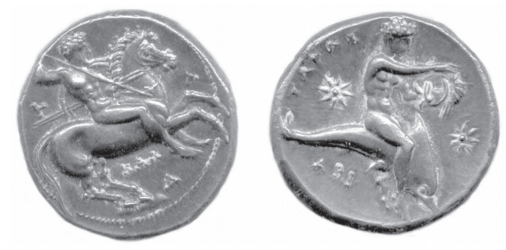

(b)

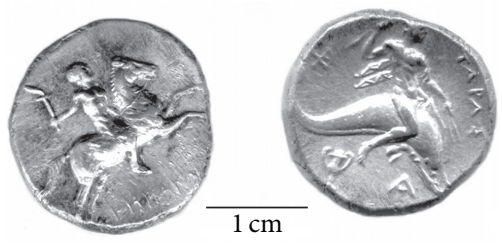

(c)

FIGURE 2: Typology of coins corresponding to the various analysed periods: (a) shows the coins Rutigliano 4 (I-1), (b) shows Carosino 28 (II), and (c) shows Parabita 135 (III-2).

of $\mathrm{V}$ and the $355 \mathrm{BC}$. A typical example of such coins is shown in Figure 2(a) [26].

The higher series, dated between the $500 \mathrm{BC}$ and the 455 BC, includes the Fischer-Bossert groups 2, 3, 4, and 7 that represent the more ancient minting with double relief. These coins have several types: seahorse, ecista, and the horseman (these groups will be labelled I-1). 
The second series is dated 450-425 BC (label I-2) and includes the Fischer-Bossert groups 10,12, and 14; finally the third one (label I-3) includes the Fischer-Bossert groups 27 (390-385 BC), 38, and 40 (365-355 BC). Details about chronological data and classifications are summarised in Table 1.

In literature there is no information about the chemical composition of such coin and also on metallurgical processes [27]. The lack of information cannot to be neglected because in the second half of $\mathrm{V}$ century $\mathrm{BC}$ the coinage seems quantitatively reduced and made by two different series ascribed to two distinct workshops. Just as Salvatore Garraffo's asserted, the production increased in the IV century $\mathrm{BC}$ from the Archytas' age [28].

The second group is dated $340-325 \mathrm{BC}$ and includes the Fischer-Bossert groups 58-60 (label II). A typical example of such coins is shown in Figure 2(b).

In this age, especially during the time known as "Molosso's age" (340-330 BC Molossian age strictly meant), an intense financial effort occurred. Fischer-Bossert leads a study on the analysed groups and he checked the presence of numerous die-couples with the elevated incidence of obverse dies. These two conditions coupled with the short emission period showed the "programmatic" nature of this coinage, which is assigned to support a considerable production in proximity of a war [26, 29]. The technical and numismatic complexity of Taras coinage is known, but there is a lack about chemical composition and silver percentage. These parameters should be considered also together with standards.

The aim of the work performed on this cluster is to clarify if the huge emission required by Molosso's expedition had changed or not the parameters as weight and silver percentage of previous periods. The change of these parameters should have been caused by any increased need of money.

The third group of analysed samples is composed of coins from Parabita hoard. A typical example of such coins is shown in Figure 2(c). Some pieces belong to V (Fischer-Bossert groups 68 and 75) and VI periods of Evans (label III-1). A particular attention has been also devoted to Evans VII period of Taras coinage (label III-2). Recently their chronology is placed in the first quarter of III century BC [30]. These phases of Taras coinage are known by the Evans arrangement [31]. The chronology of such period at present is not well defined: the period VI is dated by Evans between 302 and $282 \mathrm{BC}$, by Fischer-Bossert between 281 and $276 \mathrm{BC}$ [26], and by Garraffo between 282 and 280 BC [30]. Regarding the period VII, dated by Evans between 281 and 272 BC, Mattingly hypothesizes a date between 275 and 265 [32]. The study led by the Department of Cultural Heritage of the University of Salento on numerous hoards of this period allows making up the documentary base for a further investigation, enriched in documentation and updated in methodology and in technical analysis.

The chemical data contribution is very meaningful if we think over the fact that the examined period, the VII one [27], was affected by the weight loss; this loss regarded also other contemporary coinage. The nature of monetary intervention should be different if the weight loss should be associated with the alloy alteration.

\section{Materials and Methods}

The detailed morphological characterisation and the chemical identification of the coins were obtained by scanning electron microscopy (SEM). Because the analysed coins are precious historical artefacts and they cannot endure some type of cleaning, SEM observation was performed at low vacuum mode without any kind of polishing and without covering by a conductive layer. The scanning electron microscope Jeol model JSM 5410-LV was used coupled to an Oxford Link ISIS 300 Series energy-dispersive spectrometer having a $\mathrm{Si}(\mathrm{Li})$ windowless detector to perform energy dispersive $\mathrm{X}$-ray microanalysis (EDX). This apparatus allows $156 \mathrm{eV}$ resolution.

Four coins, which were from the numismatic point of view in bad conditions and were already in fragments, were embedded in epoxy resin and sectioned by using a diamond saw in order to preserve the corrosion products. The sections were polished with silicon carbide papers down to 1200 grit and the final polishing was performed with diamond pastes up to $(1 / 4) \mu \mathrm{m}$ order to have mirror-like polished surfaces [33].

For quantitative analysis, areas of surface metal of approximately $150 \times 100 \mu \mathrm{m}^{2}$ were scanned. Analysis was carried out on areas as large as possible in order to avoid small inhomogeneities of the bulk composition and effects caused by surface corrosion. In general, twenty analyses were performed on each side of each coin (reverse and obverse) and the mean value was calculated. It was attempted to perform analysis on areas which were not affected from corrosion yet. SEM images were obtained by secondary electrons with an accelerating voltage of $20 \mathrm{keV}$ and a beam current of $90 \mu \mathrm{A}$. An X-ray spectrum was collected for $300 \mathrm{sec}$ for every SEM image.

In order to evaluate the possible silver surface enrichment, on the cross-sections of the coin fragments minted in the Greek colony of Caulonia and of Metapontum [34], one hundred points were analysed for each fragment. In particular, the ordered point set defines a matrix with twentyfive lines and four columns, and these lines, $30 \mu \mathrm{m}$ separated from each other, are composed of points whose distance from the coin surface varies up to $300 \mu \mathrm{m}$. A typical matrix of points of measurement is shown in Figure 3. From each point of the matrix, an X-ray spectrum was collected for $300 \mathrm{sec}$ in order to analyse the variations of silver concentration between surface and bulk.

The quantification of X-ray spectra was performed by applying ZAF4/FLS Link ISIS Oxford quantitative analyses software.

$\mathrm{X}$-ray fluorescence analysis was performed by an X-ray Micro Analyser UNISANTIS model XMF-104, equipped with a $50 \mathrm{~W}$ molybdenum tube and a high resolution two-stage Peltier cooled, compact Si-PIN detector. Typical diameter of the focal spot of the X-ray beam, at the exit of the polycapillary focusing lens, was about $150 \mu \mathrm{m}$.

The main difference between XRF and SEM-EDX is the different information depth. For XRF the depth of information for $\mathrm{Ag}-\mathrm{K}_{\alpha}$ radiation is up to $150 \mu \mathrm{m}$, depending on the matrix composition, whereas for $\mathrm{Cu}-\mathrm{K}_{\alpha}$ the higher 
TABLE 1: Chronology of coins analysed in this project. The coins are marked in accordance with recovery site and progressive number position in collection drawers of the National Archaeological Museum of Taranto and dated according to the classification performed by FischerBossert [26]. For group III also the oldest Evans classification and chronology are reported by Evans [31]. Regarding Corinto and Arpi's fraction coins they are dated according to Spagnoli [40] and Siciliano [41], respectively.

\begin{tabular}{|c|c|c|c|}
\hline Heap label & Coin mark & Chronology & References \\
\hline I-1 & Rutigliano 1 & $500-490 \mathrm{BC}$ & Fischer-Bossert 1999 [26] \\
\hline $\mathrm{I}-1$ & Rutigliano 2 & $490-480 \mathrm{BC}$ & Fischer-Bossert 1999 [26] \\
\hline $\mathrm{I}-1$ & Rutigliano 3; 4 & $480-470 \mathrm{BC}$ & Fischer-Bossert 1999 [26] \\
\hline $\mathrm{I}-1$ & Torchiarolo, 1927: 2 & $470-455$ BC & Fischer-Bossert 1999 [26] \\
\hline I-1 & Carosino 1 & $465-455$ BC & Fischer-Bossert 1999 [26] \\
\hline $\mathrm{I}-2$ & Montegranaro 5 & $450 \mathrm{BC}$ & Fischer-Bossert 1999 [26] \\
\hline $\mathrm{I}-2$ & Torchiarolo, 1926: 3, Montegranaro 2; 3; 4 & $450-440 \mathrm{BC}$ & Fischer-Bossert 1999 [26] \\
\hline $\mathrm{I}-2$ & Montegranaro 6, Torchiarolo, 1926: 4 & $445-440 \mathrm{BC}$ & Fischer-Bossert 1999 [26] \\
\hline $\mathrm{I}-2$ & Carosino 3; 4, Maruggio 1 & $430-425$ BC & Fischer-Bossert 1999 [26] \\
\hline $\mathrm{I}-2$ & Carosino 2, Taranto V. Oberdan 1; 2 & $430-425 \mathrm{BC}$ & Fischer-Bossert 1999 [26] \\
\hline $\mathrm{I}-3$ & Torchiarolo, 1927: 3 & $390-385$ BC & Fischer-Bossert 1999 [26] \\
\hline $\mathrm{I}-3$ & Taranto Corti Vecchie $1 ; 2 ; 9 ; 10 ; 11 ; 12$ & $365-355 \mathrm{BC}$ & Fischer-Bossert 1999 [26] \\
\hline $\mathrm{I}-3$ & Taranto Corti Vecchie $3 ; 4 ; 6 ; 8 ; 14$ & $365-355 \mathrm{BC}$ & Fischer-Bossert 1999 [26] \\
\hline II & Carosino 22; 24; 26 & $333-331 / 0 \mathrm{BC}$ & Fischer-Bossert 1999 [26] \\
\hline II & Carosino $32 ; 33 ; 34 ; 35$ & $333-331 / 0 \mathrm{BC}$ & Fischer-Bossert 1999 [26] \\
\hline II & Carosino $27 ; 28 ; 29 ; 31$ & $333-331 / 0 \mathrm{BC}$ & Fischer-Bossert 1999 [26] \\
\hline \multirow{2}{*}{ III-1 } & \multirow{2}{*}{ Parabita $16 ; 18 ; 20 ; 23 ; 24$} & $315-300 \mathrm{BC}$ & Fischer-Bossert 1999 [26] \\
\hline & & $302-281 \mathrm{BC}$ & Evans 1889 [31] \\
\hline III-2 & Parabita $34 ; 35$ & $281-272$ BC & Evans 1889 [31] \\
\hline $\mathrm{C}$ & Mesagne 1 & $340-310 \mathrm{BC}$ & Spagnoli 1993 [40] \\
\hline $\mathrm{C}$ & Mesagne 2 & $305-295$ BC & Spagnoli 1993 [40] \\
\hline $\mathrm{C}$ & Mesagne 3 & $305-295 \mathrm{BC}$ & Spagnoli 1993 [40] \\
\hline A & Torchiarolo, 1926: 1 & $279-241 \mathrm{BC}$ & Siciliano 1995 [41] \\
\hline
\end{tabular}

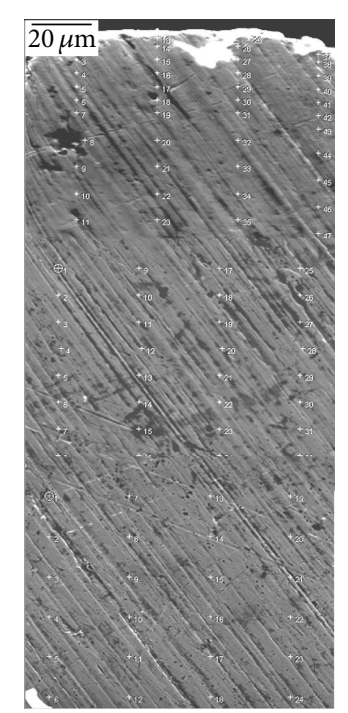

FIGURE 3: Typical matrix of points of measurement for SEM-EDX analysis.

absorption of the specific radiation compared to $\mathrm{Ag}-\mathrm{K}_{\alpha}$ results in an information depth of approximately $10-15 \mu \mathrm{m}$. In comparison to XRF, the information depth of SEM-EDX is usually stated to be $1-5 \mu \mathrm{m}$, which yields just to a surface specific information [18].

\section{Calibration Curves}

The first step of the SEM-EDX analysis was to set the calibration curves by means of silver-copper standards of various compositions, reflecting the composition of silver blanks, by using two different energies of electron incident beam $(20 \mathrm{keV}$ and $30 \mathrm{keV})$. It was possible to test the reliability of results within an experimental error less than $2 \%$. The thickness of the standards is equal to $2 \mathrm{~mm}$, comparable with that of studied coins.

Therefore, the intensities of X-rays from the samples were compared with those emitting from the standards. As standards we used thin homogeneous layers with the following composition (Goodfellow, UK, 99.99\% pure):

$$
\begin{aligned}
& 98 \text { wt\% Ag-2 wt\% Cu; } \\
& 95 \text { wt\% Ag-5 wt\% Cu; } \\
& 90 \text { wt\% Ag-10 wt\% Cu; } \\
& 80 \text { wt } \% \text { Ag-20 wt\% Cu; } \\
& 70 \text { wt } \% \text { Ag-30 wt\% Cu. }
\end{aligned}
$$




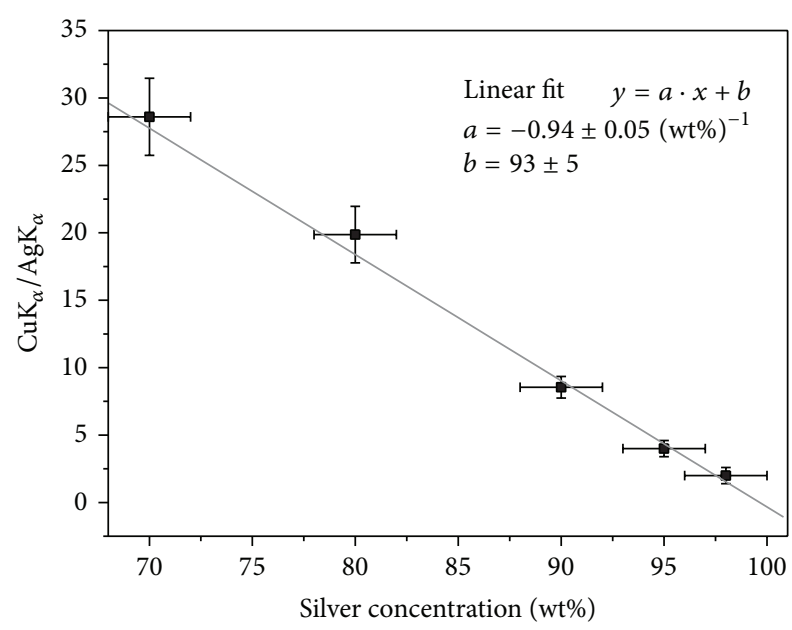

FIGURE 4: Calibration curve obtained from SEM-EDX analysis.

The apparent concentration $\left(C_{\text {apparent } X}\right)$ of every measured element " $X$ " is given up:

$$
C_{\text {apparent } X}=C_{\text {standard } X} \cdot \frac{I_{X}}{I_{\text {standard } X}},
$$

where $C_{\text {standard } X}$ is the concentration of element " $X$ " in the standard, $I_{\text {standard } X}$ is the intensity of the element " $X$ " peak in the standard spectra, and $I_{X}$ is the intensity of the element " $X$ " peak in the sample spectra.

Obviously the maximum attention had been made so that the measures of the standard and the samples had been made in the same experimental conditions.

The $C_{\text {apparent } X}$ value is corrected considering the effect of the matrix in which the element is found by applying ZAF4/FLS corrections. It must be considered that the electron penetration derives from the material atomic number (stopping power correction). A part of electrons is deflected and runs away from the sample surface (backscattering correction): the X-rays are weakened after they crossed to the sample for the same depth (absorption correction) and the Xray intensity is increased for the fluorescence effect of other $\mathrm{X}$-rays generated in the sample (fluorescence correction).

In this way calibration curves had been carried out and the dependency between the concentration of silver and the ratio of intensities between the peaks $\mathrm{Cu}-\mathrm{K}_{\alpha} / \mathrm{Ag}-\mathrm{K}_{\alpha}$ had been determined. In Figure 4 the calibration curve is shown. It is possible to notice that the dependency is linear and it is possible to carry out information of $\mathrm{Ag} / \mathrm{Cu}$ relative concentration calculating the ratios of intensity of $\mathrm{Cu}-\mathrm{K}_{\alpha} / \mathrm{Ag}-$ $\mathrm{K}_{\alpha}$ signals for the samples. It is necessary to emphasise that the electron beam penetration is limited to $0.85 \mu \mathrm{m}$ at $20 \mathrm{keV}$ and to $1.56 \mu \mathrm{m}$ at $30 \mathrm{keV}$. However, taking into account the fluorescence effect, the X-rays characteristic signal coming from $20 \mu \mathrm{m}$ of depth from the surface [17].

\section{Results and Discussion}

One of the main advantages of electron microscopy coupled with microanalysis is the possibility to visualize the regions where the compositional analysis has been done. In this way, it was attempted to perform analysis on areas which were not or slightly affected from corrosion. This possibility is particularly important in the cases of coins having areas with elevated corrosion degree, as shown in Figure 5. The surface of the coins was rather rough and the granular structure is clearly evident at high magnification $[33,35]$. Cracks and holes with irregular shapes were visible, too. Small particles and grains can be distinguished inside the holes. These cavities were caused by leaching and diffusion of copper during the corrosion process and the corroded areas were excluded from compositional analysis.

Another example showing the importance of visualizing and choosing the area where compositional analysis has been done is represented by regions contaminated by impurity stored in the holes, as shown in Figure 6. In Figure 7, the morphological characteristics of the typical area analysed in this work are shown; with the corresponding X-ray spectrum shown in Figure 8, this surface, pertaining to a region in relief (back of the dolphin), represents a typical example of good conservation state, and only features due to the usage of the piece are evident.

Microanalysis confirmed that silver is the main component of the coins that can be assigned to the class of Ag$\mathrm{Cu}$ alloys where the copper content ranges from 0.17 to 17.1 weight percent (wt\%). Other elements could also be detected as minor elements; they can be divided in two categories: those that could be explained by alloying additives or by impurities within the alloy ( $\mathrm{Sn}, \mathrm{Zn}, \mathrm{Au}, \mathrm{Hg}, \mathrm{Pb}$, and $\mathrm{Bi}$ ) and those generally attributed to external pollution with dust incrusted at the surface of the metal $(\mathrm{C}, \mathrm{O}, \mathrm{Na}, \mathrm{Mg}, \mathrm{Al}, \mathrm{Si}, \mathrm{S}$, $\mathrm{Cl}$, and $\mathrm{Ca}$ ) [36]. In particular, among the impurities within the alloy, the mercury is a modern contamination. The sum of the concentration of these minor elements is expressed by $r$, residual sum, in Table 2 .

High silver content of these coins is evident that finds check in the other analyses of silver coins recovered in the other regions [35, 37]. These surface features confirm the chemical composition: it is well known that in one silvercopper alloy, as the silver content comes down under $90 \%$, the alloy will separate into two distinct phases; one is copper-rich and the other is silver-rich, the proportion of these phases being determined by the alloy composition $[35,38]$.

So, as can be seen from the phase diagram of silvercopper alloy, the presence of the copper islands in the silver alloys is a common feature of the silver-copper alloys due to the low solubility of silver in copper and vice versa at room temperature. Indeed, the solubility of copper in silver is about $8-10 \mathrm{wt} \%$ at $780^{\circ} \mathrm{C}$ (eutectic temperature) and practically nil at room temperature. Therefore, during the solidification in the copper-silver system, each component separates into a nearly pure state and has the same crystal lattice as the respective supersaturated solid solution. As a consequence, dispersed copper islands are formed in the silver matrix. The size of copper islands is influenced by the cooling parameters $[33,34]$. The occurrence of this phenomenon is well described in Figure 9 where SEM images and X-ray maps for the surface of coin are reported. The maps show the separation of copper (Figure 9(b)) and silver (Figure 9(c)) with the formation of 
TABLE 2: Chemical composition of the analysed coins obtained by SEM-EDX analysis.

\begin{tabular}{|c|c|c|c|c|c|c|c|c|c|}
\hline Coin mark & $\begin{array}{c}\mathrm{Ag} \\
(\mathrm{wt} \%)\end{array}$ & $\begin{array}{c}\mathrm{Cu} \\
(\mathrm{wt} \%) \\
\end{array}$ & $\begin{array}{c}\mathrm{Sn} \\
(\mathrm{wt} \%)\end{array}$ & $\begin{array}{c}\mathrm{Zn} \\
(\mathrm{wt} \%)\end{array}$ & $\begin{array}{c}\mathrm{Au} \\
(\mathrm{wt} \%)\end{array}$ & $\begin{array}{c}\mathrm{Hg} \\
(\mathrm{wt} \%)\end{array}$ & $\begin{array}{c}\mathrm{Pb} \\
(\mathrm{wt} \%)\end{array}$ & $\begin{array}{c}\mathrm{Bi} \\
\text { (wt\%) }\end{array}$ & $\begin{array}{c}r \\
(w t \%)\end{array}$ \\
\hline Rutigliano 1 & 97.2 & 0.58 & 0.01 & 0.02 & 0.03 & 0.02 & 0.02 & 0.02 & 2.1 \\
\hline Rutigliano 2 & 97.5 & 0.46 & 0.01 & 0.01 & 0.02 & 0.01 & 0.03 & 0.02 & 1.94 \\
\hline Rutigliano 3 & 95 & 2.38 & 0.01 & 0.01 & 0.05 & 0.03 & 0.03 & 0.02 & 2.47 \\
\hline Rutigliano 4 & 98.1 & 0.16 & 0.01 & 0.01 & 0.04 & 0.01 & 0.01 & 0.01 & 1.65 \\
\hline Torchiarolo 272 & 96 & 0.27 & 0.01 & 0.01 & 0.05 & 0.01 & 0.05 & 0.03 & 3.57 \\
\hline Carosino 1 & 95.7 & 0.82 & 0.05 & 0.02 & 0.03 & 0.02 & 0.05 & 0.01 & 3.3 \\
\hline Torchiarolo 263 & 96.1 & 0.14 & 0.02 & 0.01 & 0.03 & 0.03 & 0.05 & 0.02 & 3.6 \\
\hline Torchiarolo 264 & 94.5 & 0.56 & 0.02 & 0.01 & 0.03 & 0.04 & 0.05 & 0.04 & 4.75 \\
\hline Montegranaro 2 & 97.9 & 0.14 & 0.02 & 0.02 & 0.04 & 0.01 & 0.02 & 0.01 & 1.84 \\
\hline Montegranaro 3 & 97.9 & 0.09 & 0.01 & 0.01 & 0.01 & 0.02 & 0.03 & 0.02 & 1.91 \\
\hline Montegranaro 4 & 97.1 & 0.53 & 0.03 & 0.01 & 0.02 & 0.01 & 0.03 & 0.02 & 2.25 \\
\hline Montegranaro 5 & 96.3 & 0.47 & 0.01 & 0.01 & 0.04 & 0.03 & 0.04 & 0.05 & 3.05 \\
\hline Montegranaro 6 & 97.7 & 0.37 & 0.01 & 0.01 & 0.01 & 0.02 & 0.05 & 0.01 & 1.82 \\
\hline Carosino 2 & 94.8 & 1.9 & 0.03 & 0.01 & 0.02 & 0.02 & 0.05 & 0.05 & 3.12 \\
\hline Carosino 3 & 94.7 & 1.01 & 0.01 & 0.02 & 0.04 & 0.04 & 0.06 & 0.04 & 4.08 \\
\hline Carosino 4 & 94 & 1.04 & 0.04 & 0.01 & 0.04 & 0.05 & 0.04 & 0.05 & 4.73 \\
\hline Maruggio 1 & 94.2 & 0.9 & 0.03 & 0.01 & 0.04 & 0.03 & 0.07 & 0.03 & 4.69 \\
\hline Taranto VO 1 & 97.6 & 0.38 & 0.01 & 0.01 & 0.02 & 0.01 & 0.03 & 0.03 & 1.91 \\
\hline Taranto VO 2 & 96 & 1.03 & 0.03 & 0.01 & 0.02 & 0.02 & 0.04 & 0.03 & 2.82 \\
\hline Torchiarolo 273 & 95.9 & 1.08 & 0.03 & 0.01 & 0.03 & 0.01 & 0.04 & 0.03 & 2.87 \\
\hline Taranto CV 1 & 95.1 & 0.45 & 0.04 & 0.02 & 0.06 & 0.04 & 0.06 & 0.01 & 4.22 \\
\hline Taranto CV 2 & 92.2 & 3.1 & 0.01 & 0.01 & 0.06 & 0.05 & 0.06 & 0.04 & 4.47 \\
\hline Taranto CV 3 & 91.7 & 4.83 & 0.01 & 0.01 & 0.03 & 0.03 & 0.05 & 0.03 & 3.26 \\
\hline Taranto CV 4 & 96.2 & 0.34 & 0.03 & 0.01 & 0.03 & 0.02 & 0.03 & 0.03 & 3.31 \\
\hline Taranto CV 6 & 93.9 & 3.1 & 0.01 & 0.01 & 0.03 & 0.02 & 0.05 & 0.02 & 2.86 \\
\hline Taranto CV 8 & 94.7 & 1.22 & 0.04 & 0.02 & 0.02 & 0.02 & 0.05 & 0.04 & 3.89 \\
\hline Taranto CV 9 & 94.9 & 0.96 & 0.01 & 0.02 & 0.04 & 0.04 & 0.05 & 0.04 & 3.94 \\
\hline Taranto CV 10 & 91.3 & 4.88 & 0.01 & 0.01 & 0.05 & 0.04 & 0.05 & 0.03 & 3.63 \\
\hline Taranto CV 11 & 94.7 & 2.24 & 0.02 & 0.01 & 0.03 & 0.02 & 0.03 & 0.03 & 2.92 \\
\hline Taranto CV 12 & 95.5 & 1.61 & 0.01 & 0.01 & 0.04 & 0.03 & 0.05 & 0.03 & 2.72 \\
\hline Taranto CV 14 & 94.1 & 2.64 & 0.01 & 0.01 & 0.04 & 0.04 & 0.04 & 0.03 & 3.09 \\
\hline Carosino 22 & 96.3 & 0.43 & 0.01 & 0.01 & 0.03 & 0.03 & 0.06 & 0.04 & 3.09 \\
\hline Carosino 24 & 96.2 & 0.63 & 0.01 & 0.02 & 0.06 & 0.02 & 0.05 & 0.03 & 2.98 \\
\hline Carosino 26 & 94.8 & 2.52 & 0.01 & 0.01 & 0.04 & 0.02 & 0.05 & 0.03 & 2.52 \\
\hline Carosino 27 & 96.9 & 0.83 & 0.01 & 0.01 & 0.04 & 0.01 & 0.03 & 0.02 & 2.15 \\
\hline Carosino 28 & 97.4 & 0.51 & 0.01 & 0.01 & 0.06 & 0.01 & 0.02 & 0.01 & 1.97 \\
\hline Carosino 29 & 96.7 & 1.09 & 0.01 & 0.01 & 0.02 & 0.02 & 0.03 & 0.02 & 2.1 \\
\hline Carosino 31 & 95.5 & 0.62 & 0.01 & 0.01 & 0.05 & 0.03 & 0.04 & 0.03 & 3.71 \\
\hline Carosino 32 & 95.6 & 1.27 & 0.01 & 0.01 & 0.05 & 0.01 & 0.04 & 0.02 & 2.99 \\
\hline Carosino 33 & 95.6 & 1.85 & 0.01 & 0.03 & 0.01 & 0.01 & 0.03 & 0.04 & 2.42 \\
\hline Carosino 34 & 96.1 & 1.02 & 0.01 & 0.01 & 0.04 & 0.02 & 0.04 & 0.03 & 2.73 \\
\hline Carosino 35 & 96.1 & 1.35 & 0.01 & 0.01 & 0.03 & 0.01 & 0.04 & 0.02 & 2.43 \\
\hline Parabita 16 & 95.7 & 1.91 & 0.01 & 0.01 & 0.03 & 0.02 & 0.04 & 0.02 & 2.26 \\
\hline Parabita 18 & 95.8 & 2.88 & 0.01 & 0.03 & 0.04 & 0.01 & 0.02 & 0.01 & 1.2 \\
\hline Parabita 20 & 97.2 & 1.31 & 0.01 & 0.01 & 0.02 & 0.01 & 0.02 & 0.01 & 1.41 \\
\hline Parabita 23 & 97.3 & 0.98 & 0.01 & 0.01 & 0.03 & 0.01 & 0.03 & 0.01 & 1.62 \\
\hline Parabita 24 & 96.3 & 1.85 & 0.01 & 0.01 & 0.05 & 0.01 & 0.02 & 0.01 & 1.74 \\
\hline Parabita 34 & 79.4 & 16.9 & 0.01 & 0.01 & 0.03 & 0.03 & 0.01 & 0.02 & 3.59 \\
\hline Parabita 35 & 81.1 & 17.1 & 0.01 & 0.02 & 0.03 & 0.02 & 0.02 & 0.01 & 1.69 \\
\hline Mesagne 1 & 88.8 & 10.2 & 0.04 & 0.01 & 0.02 & 0.02 & 0.05 & 0.01 & 0.85 \\
\hline
\end{tabular}


TABLE 2: Continued.

\begin{tabular}{lccccccccc}
\hline Coin mark & $\begin{array}{c}\mathrm{Ag} \\
(\mathrm{wt} \%)\end{array}$ & $\begin{array}{c}\mathrm{Cu} \\
(\mathrm{wt} \%)\end{array}$ & $\begin{array}{c}\mathrm{Sn} \\
(\mathrm{wt} \%)\end{array}$ & $\begin{array}{c}\mathrm{Zn} \\
(\mathrm{wt} \%)\end{array}$ & $\begin{array}{c}\mathrm{Au} \\
(\mathrm{wt} \%)\end{array}$ & $\begin{array}{c}\mathrm{Hg} \\
(\mathrm{wt} \%)\end{array}$ & $\begin{array}{c}\mathrm{Pb} \\
(\mathrm{wt} \%)\end{array}$ & $\begin{array}{c}\mathrm{Bi} \\
(\mathrm{wt} \%)\end{array}$ & $\begin{array}{c}r \\
(\mathrm{wt} \%)\end{array}$ \\
\hline Mesagne 2 & 87.9 & 11 & 0.01 & 0.02 & 0.02 & 0.02 & 0.05 & 0.02 & 0.96 \\
Mesagne 3 & 87.8 & 10.8 & 0.01 & 0.01 & 0.02 & 0.02 & 0.06 & 0.03 & 1.25 \\
Torchiarolo 261 & 96.8 & 0.17 & 0.01 & 0.01 & 0.02 & 0.02 & 0.05 & 0.03 & 2.89 \\
\hline
\end{tabular}

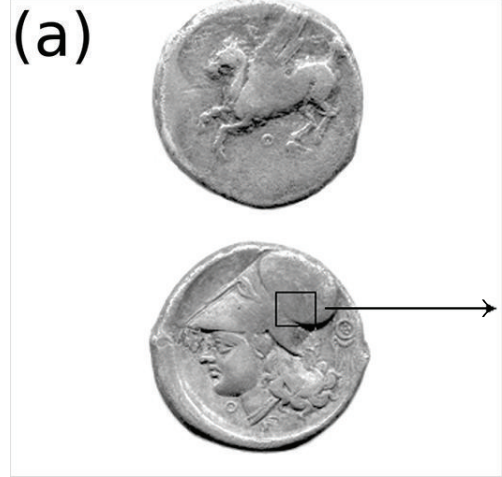

(a)

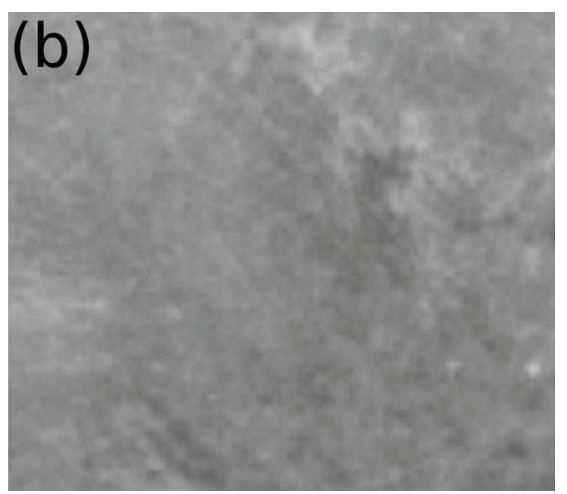

(b)

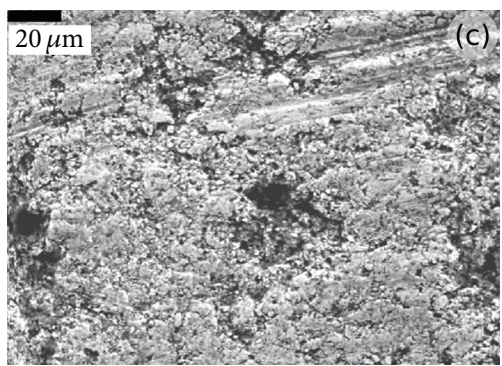

(c)

Figure 5: Coin "Mesagne 2" (a), macrophotography of the highlighted area (b), and scanning electron microscopy image of the surface. The electron microscopy shows a corroded surface.

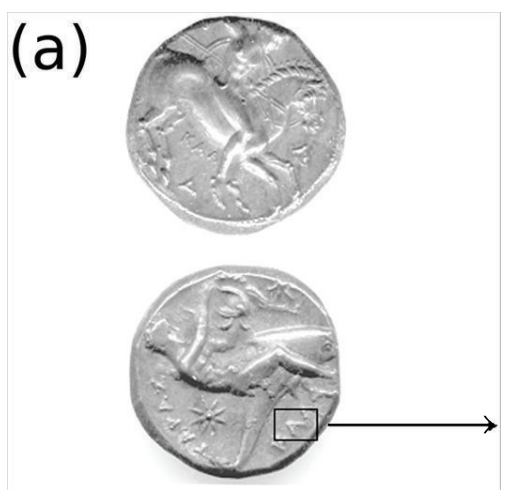

(a)

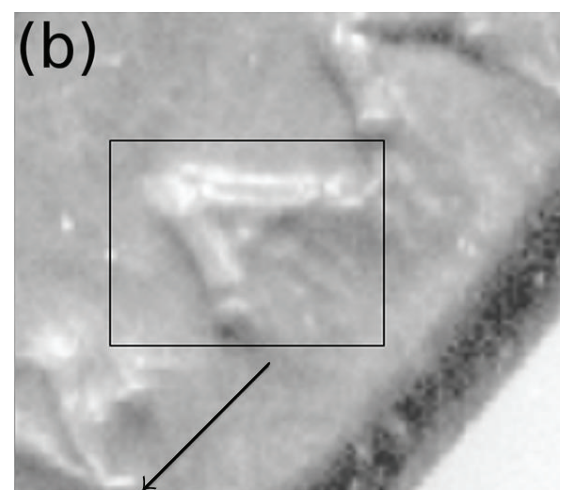

(b)

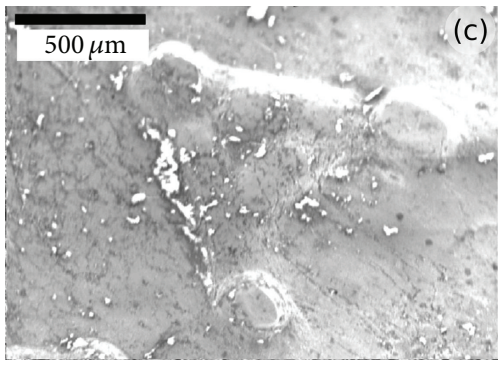

(c)

FIGURE 6: Coin "Carosino 32" (a), macrophotography of the highlighted area (b), and scanning electron microscopy image of the surface. The electron microscopy shows a contaminated surface.

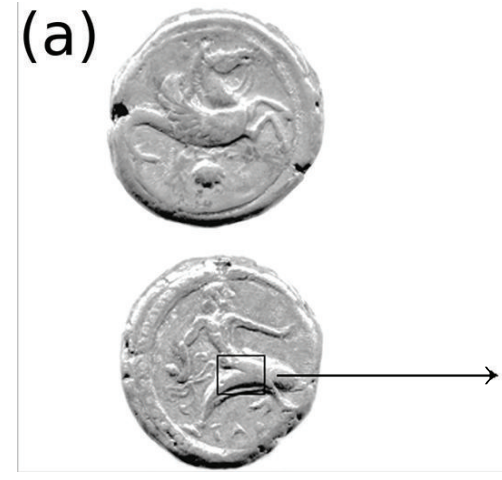

(a)

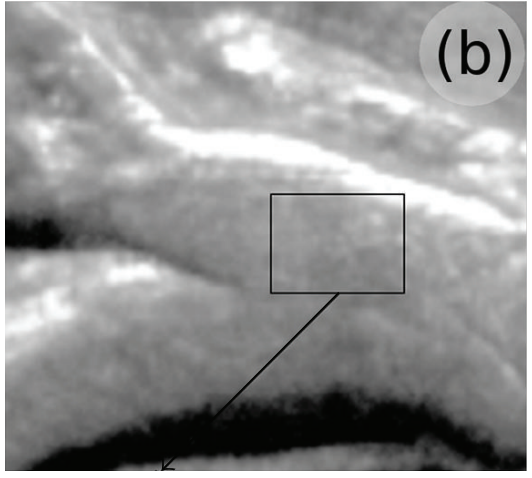

(b)

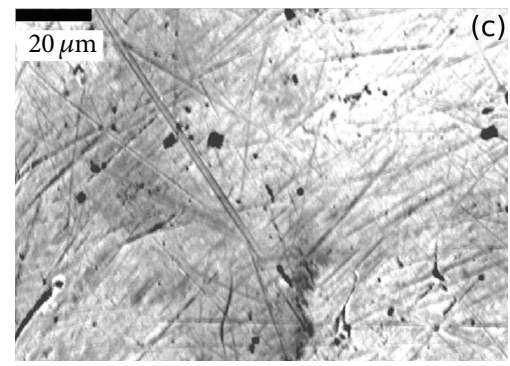

(c)

Figure 7: Coin "Rutigliano 2" (a), macrophotography of the highlighted area (b), and scanning electron microscopy image of the surface. The electron microscopy shows a good preservation state. 
TABLE 3: Chemical composition of the analysed coins obtained by XRF analysis.

\begin{tabular}{|c|c|c|c|}
\hline Coin mark & $\begin{array}{c}\mathrm{Ag} \\
(\mathrm{wt} \%)\end{array}$ & $\begin{array}{c}\mathrm{Cu} \\
(\mathrm{wt} \%)\end{array}$ & $\begin{array}{c}r \\
\text { (wt } \%)\end{array}$ \\
\hline Rutigliano 1 & 97.3 & 0.5 & 2.2 \\
\hline Rutigliano 2 & 97.6 & 0.5 & 2.3 \\
\hline Rutigliano 3 & 95.1 & 2.4 & 2.8 \\
\hline Rutigliano 4 & 98.1 & 0.2 & 1.8 \\
\hline Torchiarolo 272 & 95.8 & 0.3 & 3.7 \\
\hline Carosino 1 & 95.6 & 0.8 & 3.6 \\
\hline Torchiarolo 263 & 96.1 & 0.1 & 3.8 \\
\hline Torchiarolo 264 & 94.5 & 0.6 & 4.9 \\
\hline Montegranaro 2 & 97.8 & 0.1 & 2 \\
\hline Montegranaro 3 & 97.9 & 0.1 & 2 \\
\hline Montegranaro 4 & 97.3 & 0.5 & 2.4 \\
\hline Montegranaro 5 & 96.3 & 0.5 & 3.4 \\
\hline Montegranaro 6 & 97.7 & 0.4 & 2.1 \\
\hline Carosino 2 & 94.8 & 1.9 & 3.4 \\
\hline Carosino 3 & 94.7 & 1 & 4.4 \\
\hline Carosino 4 & 94.2 & 1 & 5 \\
\hline Maruggio 1 & 94.3 & 0.9 & 4.8 \\
\hline Taranto VO 1 & 97.6 & 0.4 & 2 \\
\hline Taranto VO 2 & 96.1 & 1 & 3 \\
\hline Torchiarolo 273 & 95.9 & 1.1 & 3 \\
\hline Taranto CV 1 & 95.2 & 0.5 & 4.5 \\
\hline Taranto CV 2 & 92.2 & 3.1 & 4.8 \\
\hline Taranto CV 3 & 91.7 & 4.8 & 3.6 \\
\hline Taranto CV 4 & 96.2 & 0.3 & 3.6 \\
\hline Taranto CV 6 & 93.8 & 3.1 & 3 \\
\hline Taranto CV 8 & 94.7 & 1.2 & 4.2 \\
\hline Taranto CV 9 & 94.9 & 1 & 4.2 \\
\hline Taranto CV 10 & 91.5 & 4.9 & 4 \\
\hline Taranto CV 11 & 94.7 & 2.2 & 3.1 \\
\hline Taranto CV 12 & 95.5 & 1.6 & 3.1 \\
\hline Taranto CV 14 & 94.1 & 2.6 & 3.2 \\
\hline Carosino 22 & 96.3 & 0.4 & 3.4 \\
\hline Carosino 24 & 96.2 & 0.6 & 3.2 \\
\hline Carosino 26 & 94.8 & 2.5 & 2.7 \\
\hline Carosino 27 & 96.9 & 0.8 & 2.4 \\
\hline Carosino 28 & 97.4 & 0.5 & 2.2 \\
\hline Carosino 29 & 96.7 & 1.1 & 2.2 \\
\hline Carosino 31 & 95.5 & 0.6 & 4 \\
\hline Carosino 32 & 95.6 & 1.3 & 3.3 \\
\hline Carosino 33 & 95.6 & 1.9 & 2.6 \\
\hline Carosino 34 & 96.3 & 1 & 2.9 \\
\hline Carosino 35 & 96 & 1.4 & 2.5 \\
\hline Parabita 16 & 95.7 & 1.9 & 2.2 \\
\hline Parabita 18 & 95.7 & 2.9 & 1.3 \\
\hline Parabita 20 & 97.2 & 1.3 & 1.6 \\
\hline Parabita 23 & 97.3 & 1 & 1.9 \\
\hline Parabita 24 & 96.4 & 1.9 & 2.1 \\
\hline Parabita 34 & 79.3 & 16.9 & 3.8 \\
\hline Parabita 35 & 81.2 & 17.1 & 1.9 \\
\hline Mesagne 1 & 88.7 & 10.2 & 3.2 \\
\hline
\end{tabular}


TABLE 3: Continued.

\begin{tabular}{lccr}
\hline Coin mark & $\mathrm{Ag}$ & $\mathrm{Cu}$ & $r$ \\
$(\mathrm{wt} \%)$ & $(\mathrm{wt} \%)$ & 11 & 2.5 \\
Mesagne 2 & 87.7 & 10.8 & 3.1 \\
Mesagne 3 & 87.9 & 0.2 & 2.9 \\
Torchiarolo 26 1 & 96.9 & 0.2 & \\
\hline
\end{tabular}

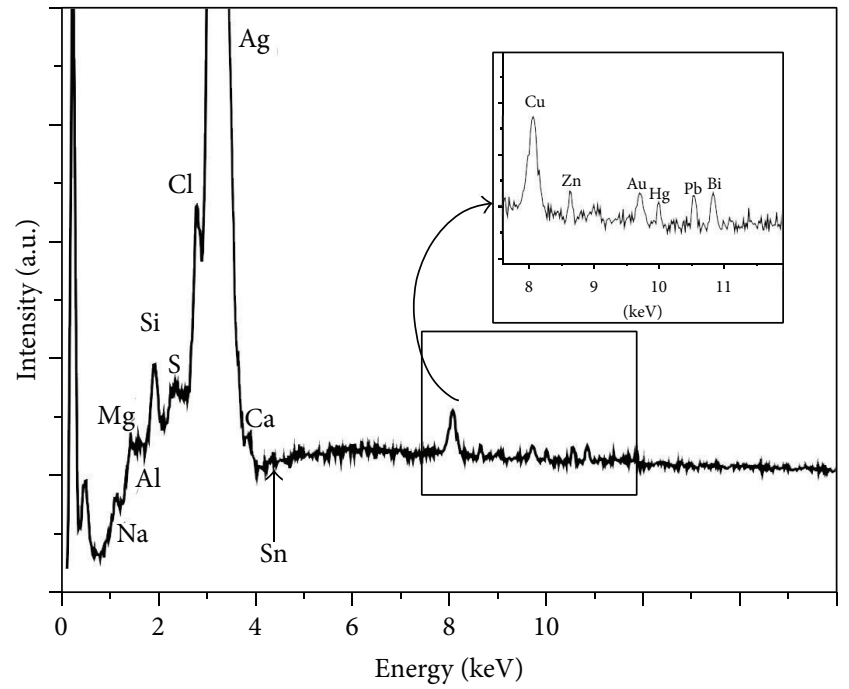

Figure 8: Typical X-ray spectra obtained at $20 \mathrm{kV}$ acceleration voltage. The identified elements can be divided in two categories: $\mathrm{Cu}, \mathrm{Zn}, \mathrm{Sn}, \mathrm{Ag}, \mathrm{Hg}, \mathrm{Pb}, \mathrm{Au}$, and $\mathrm{Bi}$ that, presumably, compose the coins alloy and $\mathrm{C}, \mathrm{O}, \mathrm{Na}, \mathrm{Al}, \mathrm{Mg}, \mathrm{Si}, \mathrm{S}, \mathrm{Cl}$, and $\mathrm{Ca}$ that are attributed to external pollution and dust incrusted at the surface of the metal.

small copper islands having size ranging between $0.2 \mu \mathrm{m}$ and $2 \mu \mathrm{m}$ scattering in the silver alloy.

It is possible, moreover, to see an emphasized phenomenon of corrosion around to grained copper: this is a consequence of the intimate contact between copper and silver that have different electrochemical potentials. Indeed, the contact induces the less noble metal to become anodic in a couple strongly conductive to corrosion, and a preferential dissolution of copper occurs in the less noble anodic areas [39].

The results obtained by microanalysis performed on the two sides of the coins were in agreement with the results obtained by the punctual X-ray spectra acquired on the crosssection of some fragments of coins. These data allowed us to get the profile of silver and copper along the depth, for the coins M2 and M6 (Figure 10). It is evident that a slight process of superficial silver enrichment occurred within the first $20 \mu \mathrm{m}$ of depth with a variation of silver concentration less than $1 \mathrm{wt} \%$. The average value of silver concentration on the surface of the fragments M2 and M6 is equal to $99.2 \pm 0.2$ (wt\%) and $98.7 \pm 0.1$ (wt\%), respectively.

This result confirms the precision and the reliability of the measurements carried out at the coin surface of the coins having a high silver content, by using the described protocol of surveying. For silver coins having low copper content
$(<3 \mathrm{wt} \%)$, the concentrations determined at the surface are also relevant for inner composition [42].

To perform the XRF analysis four regions on both sides of the coins of about $0.05 \mathrm{~mm}^{2}$ were investigated. The results are reported in Table 3 . The sum of the concentration of minor elements is expressed by $r$, residual sum.

As evident, the elemental compositions obtained by XRF and SEM-EDX are in very good agreement; the difference between the data is lower than $0.2 \%$. From the silver profile along the depth obtained by X-ray spectra and from the accordance between X-ray and XRF data, it is reasonable to suppose that EDX analysis may not significantly differ from the original bulk composition.

In conclusion of this work, the ratio between the concentration of silver and copper was calculated and elaborated in relationship with the numismatic issue (Figure 11). The cluster A has not been shown in Figure 11 since it is formed from a single coin (Torchiarolo, 1926: 1). The obtained trend shows a decrease of this ratio. In particular, the copper concentration some times is below $1 \%$ and others higher than $1 \%$. A low amount of copper (up to 1\%) plays the role of hardener for the silver alloy, while a higher amount indicates a deliberate insertion [39]. The content of silver and copper was very variable even for different emission of the same ruler, $\mathrm{Ag} / \mathrm{Cu}$ ratio being an indicator of the debasement and financial and political situation of the corresponding period. Since it is spoken about deliberately added element if those are present in greater amounts of $1 \%$ (in the plot it corresponds to $\mathrm{Ag} / \mathrm{Cu}$ ratio lower than 90), we can say that copper has been intentionally introduced in the samples of "Taranto Corti Vecchie," "Parabita," and "Mesagne." It is clearly evident that the silver content in the coins decreases considerably ranging from about $97 \%$ for the older period, down to $80 \%$ for the ones of 3rd Evans period (300-270 BC).

The results of the analysis on the chemical composition, the surface morphology, and the silver concentration and its variations together with numismatic data support the opinion of the leading role of Taras in the political and diplomatic relations with the Epirote Prince, confirms the frame of stability and economic wealth to reject the idea of weakness in the ancient town, unable to defend herself from the natives aggression [43]. At the opposite, the monetary policy seems - as the discussed data suggest - to be agreed with strategic necessities and tactics on one side and with political perspective on the other side.

For further numismatic information, see supplementary Appendix 1 available online at http://dx.doi.org/10.1155/2014/ 171243. 


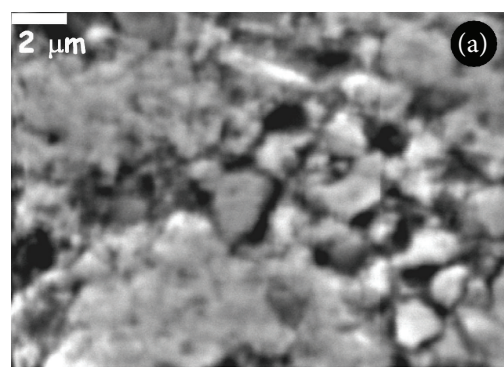

(a)

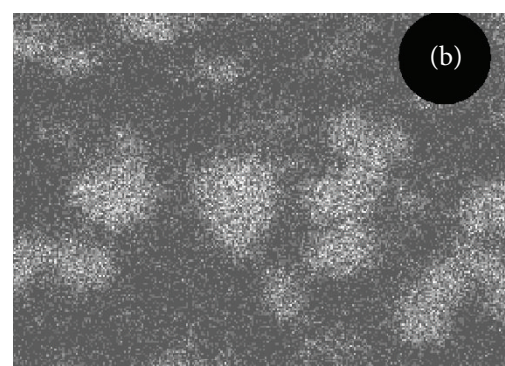

(b)

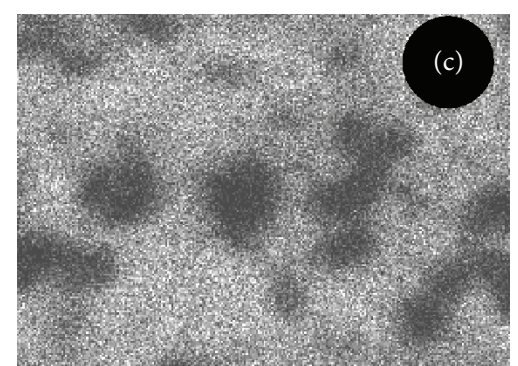

(c)

FIGURE 9: Typical electron microscopy image of a surface coin obtained bysecondary electron image (a). The corresponding X-ray maps show the separation of copper islands (b) in the silver matrix (c).

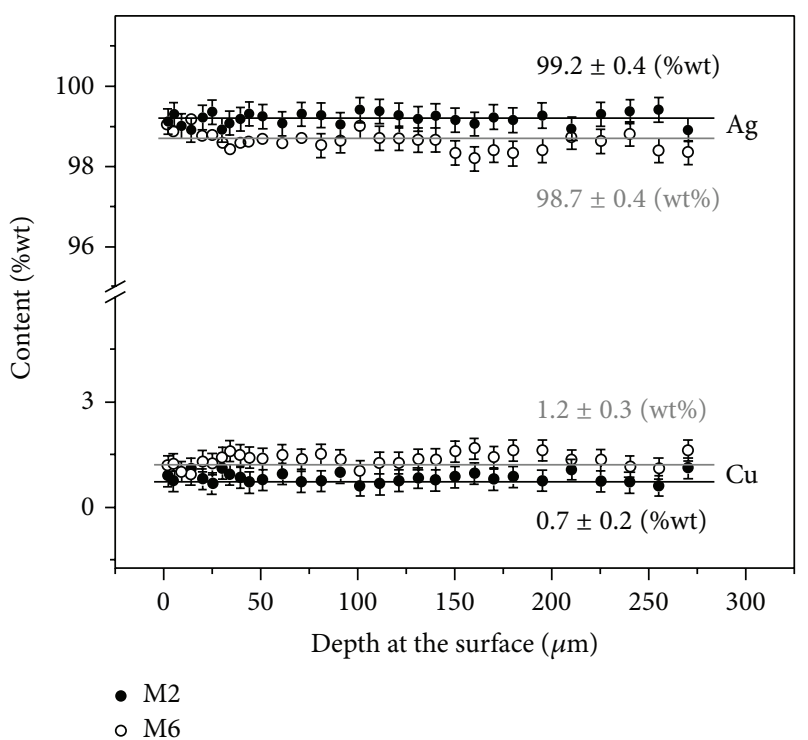

FIGURE 10: Silver and copper profile along the depth at the surface, obtained by punctual X-ray microanalysis data on coin fragments M2 and M6.

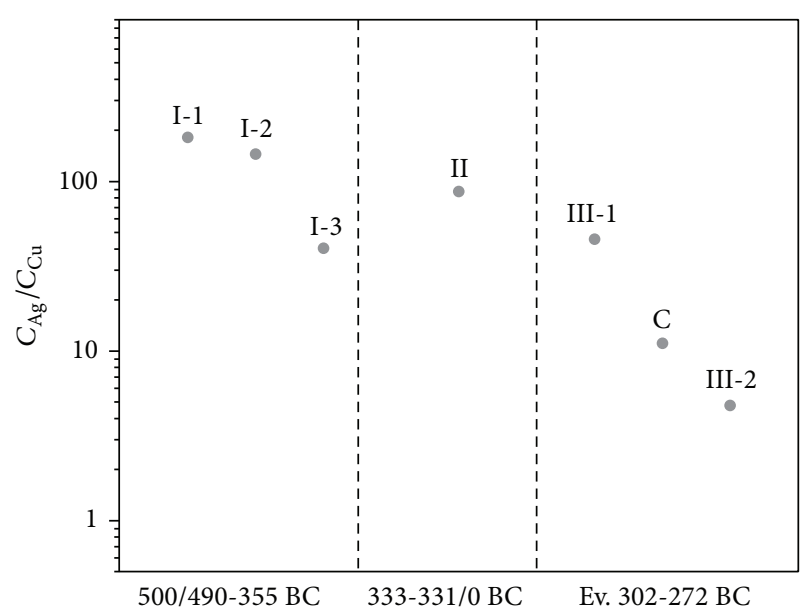

FIGURE 11: Ratios between concentrations of silver and copper, for every analysed cluster, as a function of the coinage period.

\section{Conclusions}

In this paper we have analysed forty-five ancient coins coming from collection of the National Museum of Taranto, minted by the Greek colony of Taras, between the V century BC and the III century BC. The analysed coins, famous therefore in their technical and numismatic articulation, were until now lacking in indications about the chemical composition, the superficial morphology, and, in particular, the silver concentration [25].

It is right to emphasize that all analyses were performed in great consideration of the elevated historical and artistic value of pieces, and all coins were analysed without using any hard cleaning procedure.

It is commonly stated that the main problem of SEMEDX approach to the study of ancient coins made of silvercopper alloy is its low information depth. So, this technique usually does not provide precise results in the case of surface alteration and above all in the case of silver surface enrichment. In this work, we have demonstrated that by combining image observation with simultaneous acquisition of X-ray spectrum it is possible to choose the least corroded areas of studied coins. X-ray spectra acquired on the cross-section of some coins have shown that analysed coins exhibited a corrosion layer no more than $25 \mu \mathrm{m}$ and the surface silver enrichment is scarce (less than $1 \mathrm{wt} \%)$. So, in the case of coins exhibiting corrosion layer of just a few micrometres with a scarce silver enrichment, the data obtained from surface EDX analysis may not significantly differ from the original bulk composition.

The procedure employed in this work is applicable only to silver-copper coins with silver content greater than $80 \%$ wt. Moreover, the method is time-consuming since it requires multiple data acquisitions for each coin in order to have enough number of sampling spots statistically valid as representative of composition of the coin.

\section{Conflict of Interests}

The authors declare that there is no conflict of interests regarding the publication of this paper. 


\section{References}

[1] Y. H. Tian, R. Pepelnik, and H.-U. Fanger, "Multielement analysis of archaic Chinese bronze and antique coins by fast neutron activation analysis," Journal of Radioanalytical and Nuclear Chemistry, vol. 139, no. 1, pp. 43-53, 1990.

[2] L. Daraban, C. Cosma, and T. Fiat, "X-ray fluorescence analysis of some Roman silver coins," Journal of Radioanalytical and Nuclear Chemistry, vol. 201, no. 5, pp. 447-457, 1995.

[3] E. T. Hall and D. M. Metcalf, Methods of Chemical and Metallurgical Investigation of Ancient Coiniage, Royal Numismatic Society, London, UK, 1972.

[4] M. F. Guerra, "Analysis of archaeological metals. The place of XRF and PIXE in the determination of technology and provenance," X-Ray Spectrometry, vol. 27, no. 2, pp. 73-80, 1998.

[5] M. F. Guerra, "The study of the characterisation and provenance of coins and other metalwork using XRF, PIXE and activation analysis," in Radiation in Art and Archeometry, D. C. Creagh and D. A. Bradley, Eds., pp. 378-416, Elsevier, 2000.

[6] M. F. Guerra and T. Calligaro, "Gold traces to trace gold," Journal of Archaeological Science, vol. 31, no. 9, pp. 1199-1208, 2004.

[7] R. Schwab, D. Heger, B. Höppner, and E. Pernicka, "The provenance of iron artefacts from Manching: a multi-technique approach," Archaeometry, vol. 48, no. 3, pp. 433-452, 2006.

[8] J. N. Barrandon, "Sur les traces de l'or brésilien dans les monnayages européens," Revue Européenne des Sciences Socials, vol. 45, no. 137, pp. 99-106, 2007.

[9] B. Giussani, M. Marelli, S. Recchia, F. Colpani, I. Angelini, and G. Artioli, "Tracing the provenance of ancient copper objects: a multivariate data analysis approach," in Proceedings of the 2nd International Conference on Archaeometallurgy in Europe, Aquileia, Italy, June 2007.

[10] A.-M. Desaulty, C. Mariet, P. Dillmann, J. L. Joron, and P. Fluzin, "A provenance study of iron archaeological artefacts by Inductively Coupled Plasma-Mass Spectrometry multielemental analysis," Spectrochimica Acta B: Atomic Spectroscopy, vol. 63, no. 11, pp. 1253-1262, 2008.

[11] Z. Sándor, S. Tölgyesi, I. Gresits, and Z. Kasztovszky, "Determination of the alloying elements in ancient silver coins by X-ray fluorescence," Journal of Radioanalytical and Nuclear Chemistry, vol. 254, no. 2, pp. 283-288, 2002.

[12] J. Condamin and M. Picon, "The influence of corrosion and diffusion on the percentage of silver in Roman Denarii," Archaeometry, vol. 7, pp. 98-105, 1964.

[13] J. Condamin and M. Picon, Methods of Chemical and Metallurgical Investigation of Ancient Coinage, vol. 8, Royal Numismatic Society Special Publication, London, UK, 1970.

[14] L. Beck, S. Besonnet, S. Réveillon, D. Eliot, and F. Pilon, "Silver surface enrichment of silver-copper alloys: a limitation for the analysis of ancient silver coins by surface techniques," Nuclear Instruments and Methods in Physics Research B: Beam Interactions with Materials and Atoms, vol. 226, no. 1-2, pp. 153162, 2004.

[15] R. Klockenkämper, H. Hubert, and K. Hasler, "Detection of near-surface silver enrichment on Roman imperial silver coins by X-ray spectral analysis," Archaeometry, vol. 41, no. 2, pp. 311320, 1999.

[16] A. Gianoncelli and G. Kourousias, "Limitations of portable XRF implementations in evaluating depth information: an archaeometric perspective," Applied Physics A: Materials Science and Processing, vol. 89, no. 4, pp. 857-863, 2007.
[17] A. Serra, D. Manno, E. Filippo et al., "Unusual coin from the Parabita hoard: combined use of surface and micro-analytical techniques for its characterisation," Journal of Cultural Heritage, vol. 11, no. 2, pp. 233-238, 2010.

[18] R. Linke and M. Schreiner, "Energy dispersive X-ray fluorescence analysis and X-ray microanalysis of medieval silver coins: an analytical approach for non-destructive investigation of corroded metallic artifacts," Mikrochimica Acta, vol. 133, no. 1-4, pp. 165-170, 2000.

[19] J. N. Barrandon and C. Brenot, "Recherches sur le monnayage d'argent de Marseille," Mélanges de l'École française de Rome, Antiquité, vol. 90, no. 2, pp. 637-668, 1978.

[20] H. Nicolet-Pierre, J. N. Barrandon, and J. Y. Calvez, "Monnaies archaïques d'Athènes sous Pisistrate et les Pisistratides (c. 545-c. 510) II. Recherches sur la composition métallique des Wappenmünzen," Revue Numismatique, vol. 6, no. 27, pp. 2344, 1985.

[21] N. Kallithrakas-Kontos, A. A. Katsanos, C. Potiriadis, M. Oeconomidou, and J. Touratsoglou, "PIXE analysis of ancient Greek copper coins minted in Epirus, Illyria, Macedonia and Thessaly," Nuclear Instruments and Methods in Physics Research B: Beam Interactions with Materials and Atoms, vol. 109-110, pp. 662-666, 1996.

[22] N. Kallithrakas-Kontos, A. A. Katsanos, and J. Touratsoglou, "Trace element analysis of Alexander the Great's silver tetradrachms minted in Macedonia," Nuclear Instruments and Methods in Physics Research B: Beam Interactions with Materials and Atoms, vol. 171, no. 3, pp. 342-349, 2000.

[23] B. Constantinescu, A. Săşianu, and R. Bugoi, "Adulterations in first century BC: the case of Greek silver drachmae analyzed by X-ray methods," Spectrochimica Acta B: Atomic Spectroscopy, vol. 58 , no. 4, pp. 759-765, 2003.

[24] A. Pitarch and I. Queralt, "Energy dispersive X-ray fluorescence analysis of ancient coins: the case of Greek silver drachmae from the Emporion site in Spain," Nuclear Instruments and Methods in Physics Research B: Beam Interactions with Materials and Atoms, vol. 268, no. 10, pp. 1682-1685, 2010.

[25] A. M. Burnett and D. R. Hook, "The fineness of silver coins in Italy and Rome during the late fourth and third centuries B.C.", Quaderni Ticinesi: numismatica e antichità classiche, vol. 18, pp. 151-167, 1989.

[26] W. Fischer-Bossert, Cronologie Der Didrachmenpaegung Von Tarent 510-280 V. Chr, 1999.

[27] W. Hollstein, "Die Didrachmenpraegung Sueditaliens und Roms im 3. Jh. V. Chr," in MetallAnalytische Untersuchungen An Muenzen Der Roemischen Republik, W. Hollstein, Ed., pp. 73101,2000

[28] S. Garraffo, "Aspetti e momenti della monetazione tarantina trenta'anni dopo, in Taranto e il Mediterraneo," in Atti del XLI Convegno di Studi sulla Magna Grecia, pp. 469-482, Taranto, Canada, 2002.

[29] M. Talercio Mensitieri, "La documentazione numismatica, in Alessandro il Molosso e i "condottieri" in Magna Grecia," in Atti del XLIII Convegno di Studi sulla Magna Grecia, pp. 401-431, Taranto, Canada, 2003.

[30] S. Garraffo, "Considerazioni sui Cavalieri tarantini del VI periodo Evans," in Magna Grecia e Sicilia nella prima età di Pirro, DArch, 1989.

[31] A. J. Evans, The Horsemen of Tarentum, Kessinger Publishing, London, UK, 1889. 
[32] H. B. Mattingly, From Coins to history: Selected Numismatic Studies, University of Michigan Press, Ann Arbour, Mich, USA, 2004.

[33] G. M. Ingo, S. Balbi, T. De Caro, I. Fragalà, E. Angelini, and G. Bultrini, "Combined use of SEM-EDS, OM and XRD for the characterization of corrosion products grown on silver roman coins," Applied Physics A: Materials Science and Processing, vol. 83, no. 4, pp. 493-497, 2006.

[34] G. Giovannelli, S. Natali, B. Bozzini, A. Siciliano, G. Sarcinelli, and R. Vitale, "Microstructural characterization of early western Greek incuse coins," Archaeometry, vol. 47, no. 4, pp. 817833, 2005.

[35] K. Butcher and M. Ponting, "The Roman denarius under the Julio-Claudian emperors: mints, metallurgy and technology," Oxford Journal of Archaeology, vol. 24, no. 2, pp. 163-197, 2005.

[36] C. Flament and P. Marchetti, "Analysis of ancient silver coins," Nuclear Instruments and Methods in Physics Research B: Beam Interactions with Materials and Atoms, vol. 226, no. 1-2, pp. 179184, 2004.

[37] N. Pistofidis, G. Vourlias, E. Pavlidou et al., "On the comparative study of three silver coins of the 3rd century B.C. minted in Korkyra, Dyrrachion and by the Illyrian king Monounios," Applied Physics A: Materials Science and Processing, vol. 83, no. 4, pp. 637-642, 2006.

[38] L. Beck, E. Alloin, C. Berthier, S. Réveillon, and V. Costa, "Silver surface enrichment controlled by simultaneous RBS for reliable PIXE analysis of ancient coins," Nuclear Instruments and Methods in Physics Research B: Beam Interactions with Materials and Atoms, vol. 266, no. 10, pp. 2320-2324, 2008.

[39] B. Costantinescu, R. Bugoi, E. Oberlander-Tarnoveanu, and K. Parvan, "Some consideration, on XRF use in museum measurements: the case of medieval silver coins," Romanian Reports in Physics, vol. 57, pp. 953-963, 2005.

[40] E. Spagnoli, "Presenza monetale di Corinto e colonie in Sicilia e Magna Grecia nel IV e nel III secolo a.C., in La monetazione corinzia in Occidente," in Atti IX Convegno del Centro Internazionale di Studi Numismatici, pp. 87-293, Roma, Italy, 19931993.

[41] A. Siciliano, "La monetazione di Arpi," in L'Ipogeo Della Medusa, M. Mazzei, Ed., La Necropoli, Bari, Italy, 1995.

[42] L. Addicks, Silver in Industry, Reinhold Publishing, New York, NY, USA, 1940.

[43] A. Mele, M. Giangiulio, F. Frisone, and M. Lombardo, "Alessandro Il Molosso e i "Condottieri" in Magna Grecia," in Atti del XLIII Convegno di Studi sulla Magna Grecia, vol. 43, pp. 283290, Taranto, Canada, 2003. 

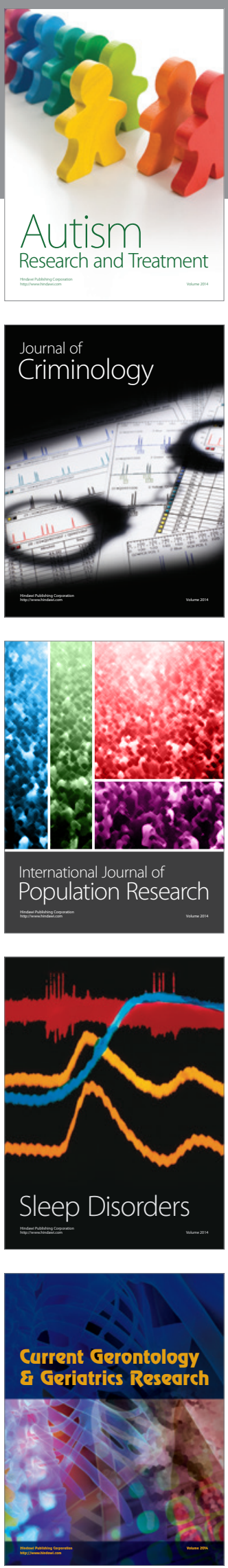
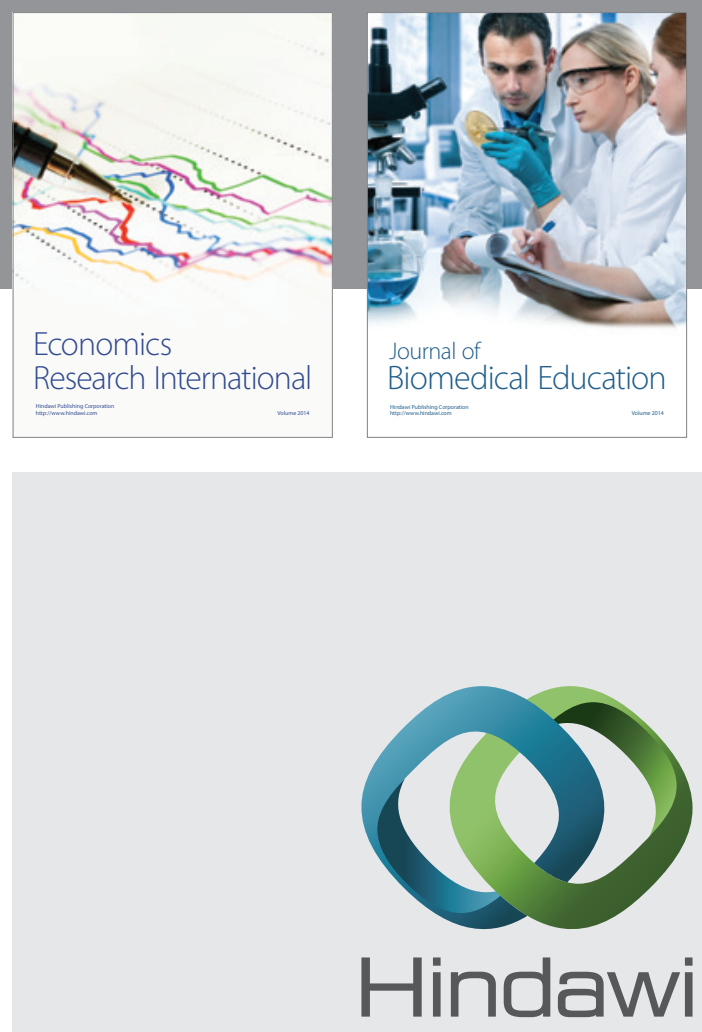

Submit your manuscripts at

http://www.hindawi.com
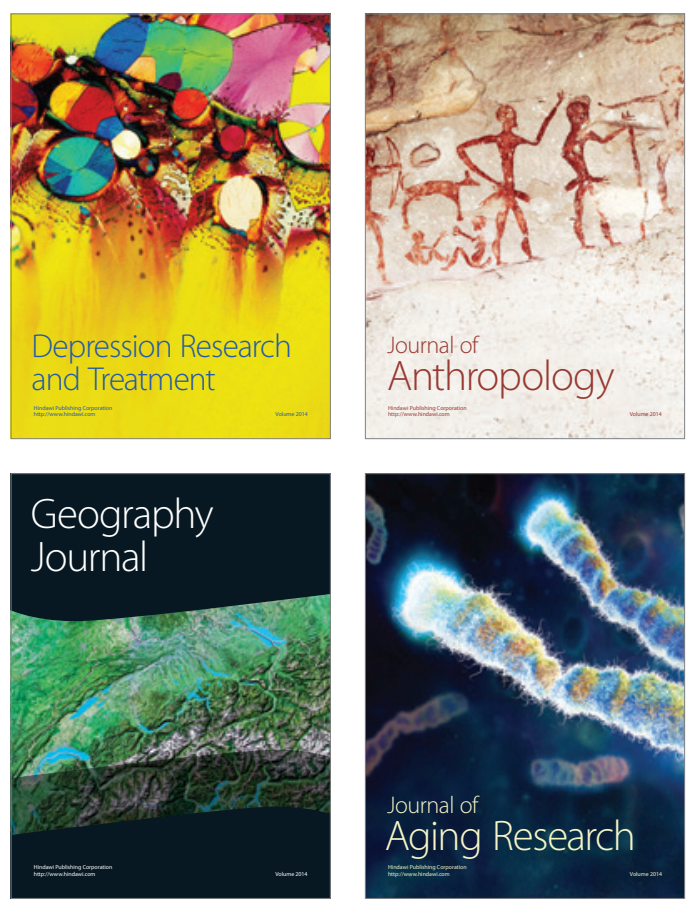
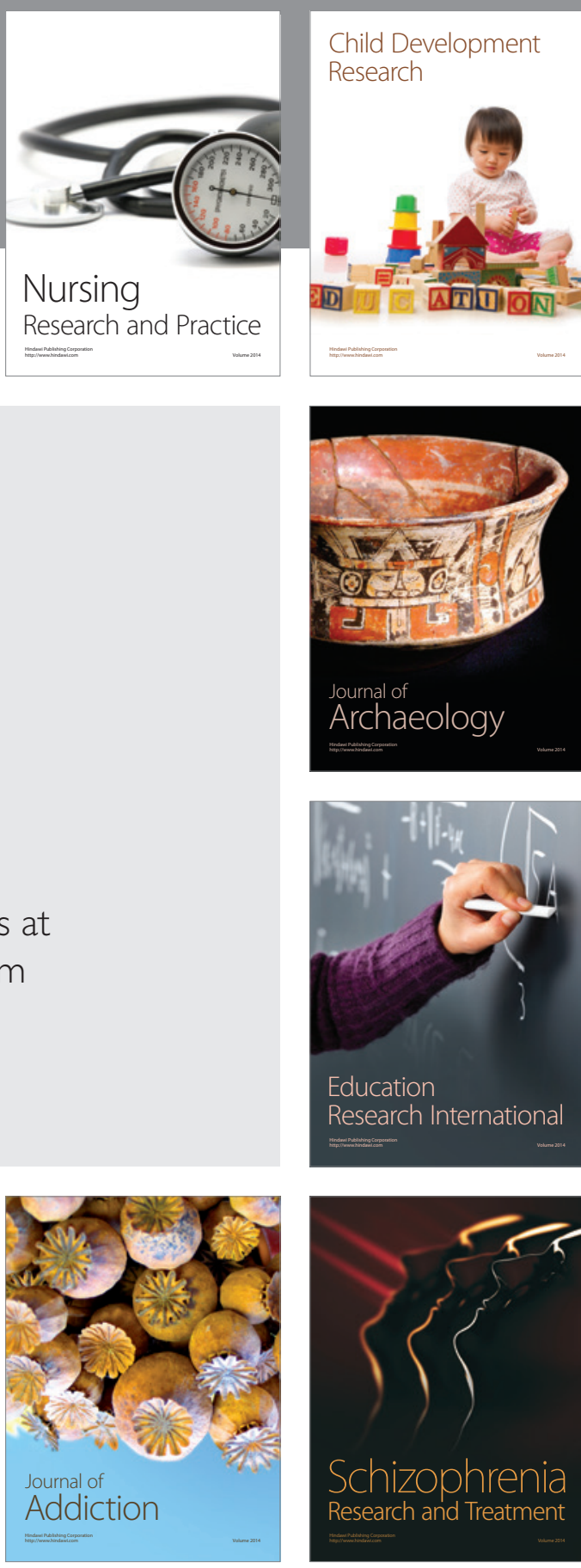

(D)
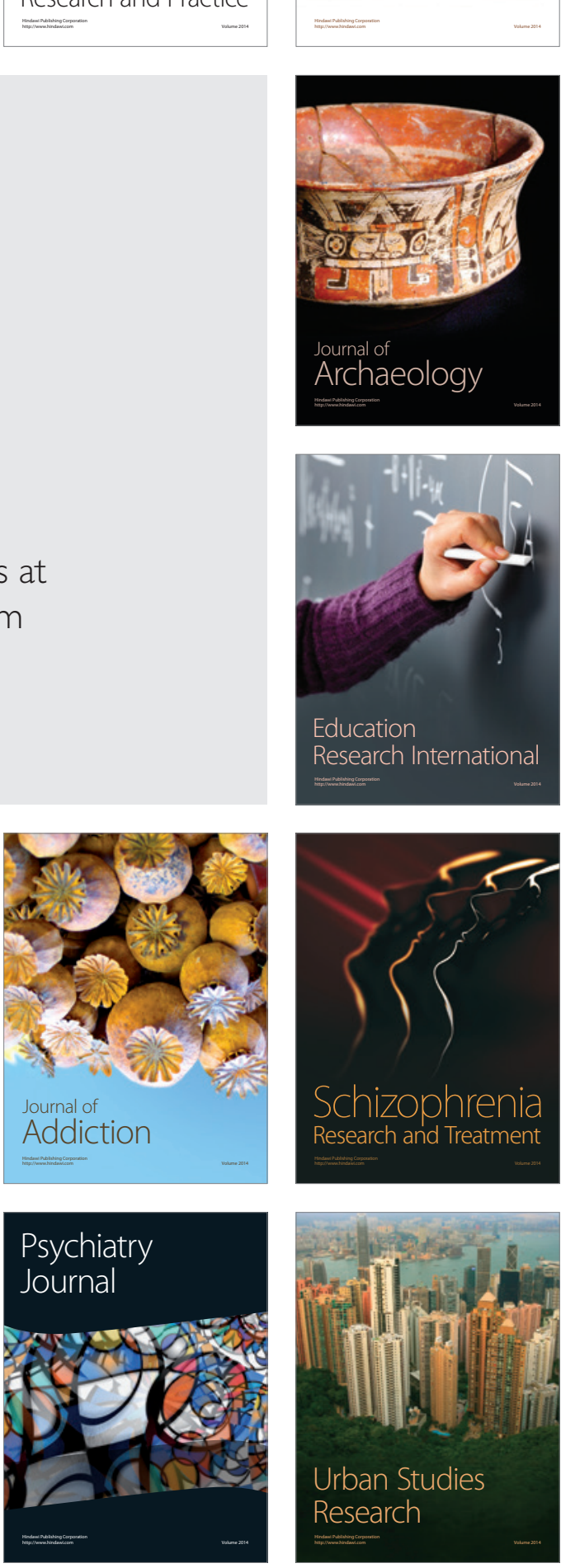